\title{
Techno-economic analysis for the integration of a power to fuel system with
}

\section{a CCS coal power plant}

\author{
D. Bellotti, A. Sorce, M. Rivarolo, L. Magistri \\ Thermochemical Power Group, University of Genoa, Italy \\ Via Montallegro 1, 16145 Genoa (Italy)
}

\section{ABSTRACT}

In this paper, an analysis of the integration of a carbon capture unit and a power to fuel system for methanol synthesis with a coal power plant is presented from the energetic, environmental and economic standpoints. The study is carried out in three different sections. In the first part, the impact of the integration of a carbon capture system (CCS ) and of a power to fuel plant (PtF) for methanol production is investigated in terms of plant average efficiency, fuel consumption, $\mathrm{CO}_{2}$ emissions. In the second part, the annual fixed and variable costs of the power plant, and the annual cost of electricity (COE) are assessed for different plant configurations. Additionally, future scenarios are analyzed considering the impact of European policies on the $\mathrm{CO}_{2}$ emission's cost, defined by the European Emission Trading System (ETS). Finally, an economic feasibility analysis of the power to fuel plant is performed and the methanol production is evaluated. Moreover, a sensitivity analysis is carried out to evaluate the impact of the most affecting parameters (electrical energy cost, the methanol selling price and the capital cost of the electrolyzer) in terms of Internal Rate of Return (IRR).

Keywords: power to fuel, $\mathrm{CO}_{2}$ Sequestration and Utilization, coal power plants, economic analysis, $\mathrm{CO}_{2}$ emission trading system.

\section{NOMENCLATURE}

$\begin{array}{ll}\text { Abbreviation } & \\ \text { CEPCI } & \text { Chemical Engineering Plant Cost Index } \\ \text { CFPP } & \text { Coal-fired power plant } \\ \text { COE } & \text { Cost Of Electricity } \\ \text { CCS } & \text { Carbon Capture Unit } \\ \text { PBP } & \text { Pay Back Period } \\ \text { EU } & \text { European Union } \\ \text { EUA } & \text { European Emission Allowances } \\ \text { ETS } & \text { Emission Trading System } \\ \text { GHG } & \text { Greenhouse gas }\end{array}$




$\begin{array}{lll}31 & \text { MEA } & \text { Methyl ethylamine } \\ 32 & \text { MPC } & \text { Methanol Production Cost } \\ 33 & \text { NPV } & \text { Net Present Value } \\ 34 & \text { PEM } & \text { Proton Exchange Membrane } \\ 35 & \text { PtF } & \text { Power to Fuel } \\ 36 & \text { RES } & \text { Renewable Energy Sources } \\ 37 & \text { TCC } & \text { Total Capital Cost } \\ 38 & \text { TPG } & \text { Thermochemical Power Group }\end{array}$

\section{INTRODUCTION}

Greenhouse gas (GHG) emissions are one of the most important environmental issues of the $21^{\text {st }}$ century. The largest source of GHG is carbon dioxide $\left(\mathrm{CO}_{2}\right)$, whose emissions have increased in the last decades, due to anthropogenic activities, in particular, fossil fuels combustion (i.e. for electrical energy production). In order to limit the effects related to $\mathrm{CO}_{2}$ increase, the European Union (EU), promoted the Emission Trading System (ETS): the EU ETS, set up on $1^{\text {st }}$ January 2005 , operates in 31 Countries (28 EU Countries, plus Iceland, Lichtenstein and Norway) and represents the largest world's platform of this kind [1]. The EU ETS works on the 'cap and trade' principle. A cap is set on the total amount of certain GHGs that can be emitted by installations covered by the system: within the cap, companies receive or buy emission allowances, which they can trade with one another as needed. After each year, a company must surrender enough allowances to cover all its emissions, otherwise heavy fines are imposed. EU ETS limits emissions for more than 10,000 energy-intensive companies and airlines operating in the above-mentioned Countries.

EU energy policy targets, already defined for 2020- and 2030-time horizons [2], include also higher and higher penetration of renewable energy sources (RES) and the promotion of energy efficiency. In particular, the recent increase of RES (i.e. solar and wind) has caused significant issues in the management of traditional large size power plants (e.g. coal steam power plants and natural gas combined cycles), forcing them to operate in off-design, with frequent startup/shutdown that reduce their efficiency and lifetime. Because of the above-mentioned policies, hard coal consumptions in EU 28 in the period $1990-2016$ have reduced significantly, from around 450 Mtons up to 239 Mtons; in a similar way, also lignite's consumption has decreased in the same period, by more than $40 \%$, compared to 1990 levels [3].

Power-to-fuel (PtF) systems can be a worthy solution for the future energy scenarios: a PtF technology concerns a process that is able to store electrical energy (i.e. produced by large size power plants) into a chemical form, to be employed in a second time [4]. The conversion of electrical energy into more convenient forms of energy carriers can represent a way to increase the efficiency of large size power plants otherwise forced to operate at partial loads and lower efficiencies due to the presence of 
new kind of production plants based on RES. Moreover, this solution allows avoiding or at least significantly reducing, the frequent shutdowns that are affecting several large size power plants.

An interesting energy carrier for the PtF systems is represented by methanol $\left(\mathrm{CH}_{3} \mathrm{OH}\right)$ : it presents liquid form at atmospheric conditions, that make its storage and handling easy and economic, and it is used for the synthesis of important chemical derivatives such as formaldehyde, MTBE and acetic acid [5].

Moreover methanol has excellent combustion properties: in fact, thanks to its high octane number (108 for methanol, 95 for gasoline), it allows higher pressures in the combustion chamber, with consequent efficiency increase when used within an internal combustion engine [6][7]. Specific energy applications were developed basing on Fuel Cell focusing on portable generation: in standard applications with a reformer plus a PEMFC or SOFC [8][9][10] are adopted while when a low temperature is crucial the preferred solution is a Direct Methanol Fuel Cell [11],

As already described in previous publications of the authors [12][13], methanol can be produced from a mixture of hydrogen and carbon dioxide: hydrogen is produced by water electrolysis employing electrical energy and $\mathrm{CO}_{2}$ can be sequestrated from the flue gas of traditional power plants [14][15][16][17]. This process represents an eco-friendly solution for methanol production by mitigating $\mathrm{CO}_{2}$ emissions. The catalytic reaction takes place in ranges of temperature and pressure of $250-300$ ${ }^{\circ} \mathrm{C}$ and $50-100$ bar, respectively on $\mathrm{CuO} / \mathrm{ZnO} / \mathrm{Al}_{2} \mathrm{O}_{3}$ as catalyzer [18][19]:

$$
3 \mathrm{H}_{2}+\mathrm{CO}_{2} \rightarrow \mathrm{CH}_{3} \mathrm{OH}+\mathrm{H}_{2} \mathrm{O}
$$

This work has been carried out within the contest of the EU MefCO2 (methanol fuel from $\mathrm{CO}_{2}$ ) project (accepted in SPIRE framework of the Horizon 2020 EU Research and Innovation program)[19]. The project's main target is the design of an innovative methanol production technology with a low carbon footprint: the concept of the MefCO2 is the capture and the sequestration of $\mathrm{CO}_{2}$ from fossil fuel plant and its use in reaction with hydrogen, produced by water electrolysis, in order to synthesize methanol. Several academic and industrial partners are involved in the project. The main activities of the research are (i) development of innovative catalyst for the methanol reaction from $\mathrm{H}_{2}$ and $\mathrm{CO}_{2}$; (ii) development of innovative PEM electrolyser for hydrogen production; (iii) design and installation of demonstrative pilot plant and grid integration; (iv) process optimization and thermo-economic analysis of the plant considering different economic scenarios. The activities of the University of Genoa as a project partner mainly deal with the thermo-economic analysis.

\section{METHODOLOGY}


In this paper, the integration of a Carbon Capture Unit (CCS) and a power-to-fuel (PtF) plant for methanol production with a traditional coal power plant is investigated.

The analysis results are presented in different sections.

- Part I-Technical Analysis: the impact of the CCS integration and of a connection of a PtF plant is investigated in terms of plant average efficiency, fuel consumption, $\mathrm{CO}_{2}$ emissions. Three different configurations are investigated, considering the CCS installation, the coupling of the coal plant with a PtF plant and the combination of the two.

- Part II - COE assessment: annual cost of electricity (COE) of the different configurations are compared, considering the annual fixed and variable costs; moreover, the impact of the forecasted increase of the $\mathrm{CO}_{2}$ cost was investigated to compare the COE of the proposed solutions over the years.

- PtF economic sensitivity analysis: focusing on the PtF plant for methanol production, an economic feasibility analysis is performed in order to evaluate the viability of the system in terms of methanol production cost. Moreover, a sensitivity analysis is carried out to investigate the impact of some of the most affecting parameters on the Internal Rate of Return (IRR).

In the following paragraphs the main technical and economic assumption are reported.

\subsection{Plant Layouts, main hypotheses and technical assumptions}

Four different cases are analyzed and compared from the energetic, economic and environmental standpoints:

- $\quad$ CASE 1 - Reference case: 300MW coal-fired power plant without a system for the CO2 capture.

- $\quad$ CASE 2 - 300MW coal-fired power plant with CCS integration: a system for the carbon capture is assumed to be installed and its impact in terms of plant performance, costs and emission is investigated.

- $\quad$ CASE 3 - 300MW coal-fired power plant with PtF plant connection: the study case including the coal power plant and the methanol plant (without the CCS system). This case is considered as a basis for comparison with Case 4.

- $\quad$ CASE 4 - 300MW coal-fired power plant with CCS integration and PtF plant connection: it is assumed to couple a methanol production plant to the coal-fired power plant equipped with the CCS system. From the energy point of view, the PtF plant is considered as an additional user of the power plant. Instead, from the CO2 management point of view, the methanol plant represents a consumer: the power plant provides the PtF plant of the necessary amount of CO2 at zero cost.

In Figure 1, a scheme of the general concept of the system under investigation is reported. 


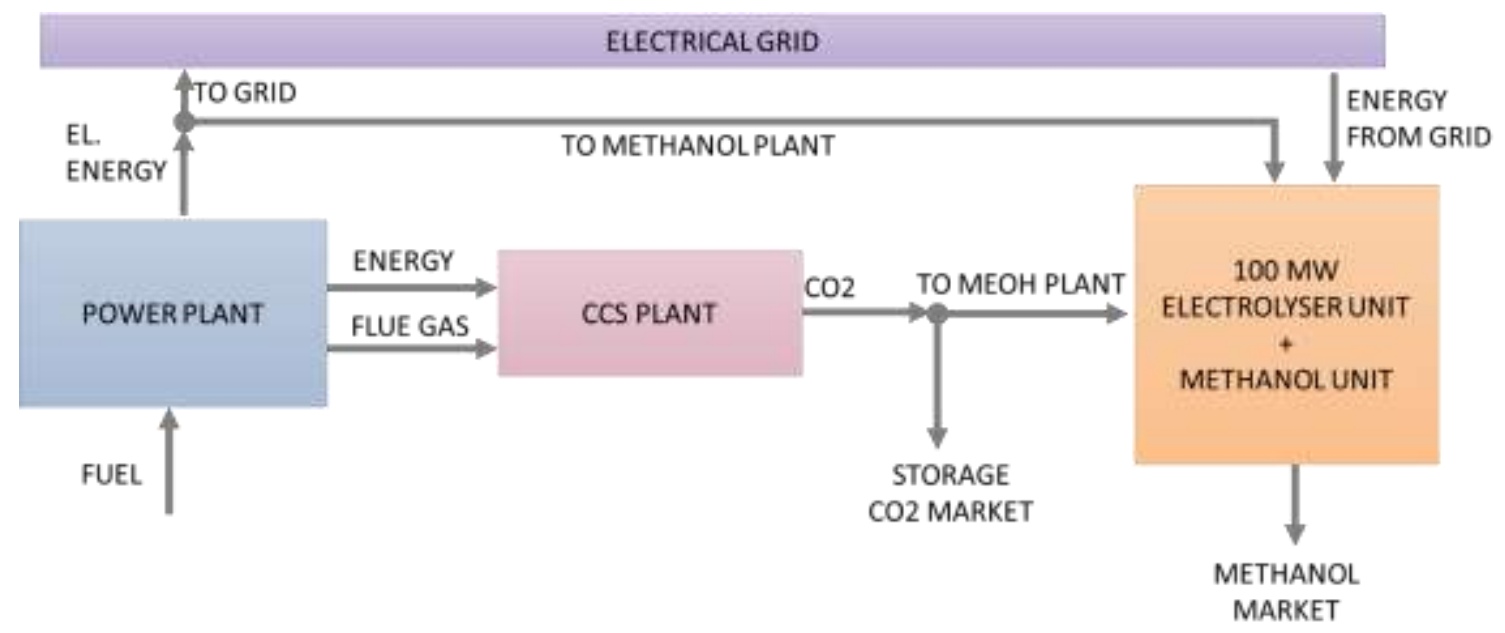

Figure 1 Concept Scheme

120 In the following, the main system components are described.

121 Coal Fired Power Plant (CFPP)

122 The reference case is represented by a $300 \mathrm{MW}$ coal-fired power plant with a nominal efficiency of $45 \%$. The minimum load is

123 fixed at $25 \%$ of the nominal power [21] and the specific $\mathrm{CO}_{2}$ emission rate based on fuel consumption is assumed equal to 0.35

$124 \mathrm{tCO} 2 / \mathrm{MW}_{\mathrm{th}}[22]$. The main technical data of the reference plant are reported in Table 1.

Table 1 Coal-fired power plant main technical data [21] [22] [23]

\begin{tabular}{|lrl|}
\hline Nominal Power & 300 & $\mathrm{MW}$ \\
Nominal efficiency & 45 & $\%$ \\
Min. Load & 25 & $\%$ Pmax \\
Plant availability & 98 & $\%$ \\
$\mathrm{CO}_{2}$ emission factor & 0.35 & $\mathrm{tCO}^{2} / \mathrm{MWh}_{\text {th }}$ \\
\hline
\end{tabular}

127 The dimensionless off-design curve of the power plant is reported in Figure 2. On its basis, the punctual efficiency of the plant 128 has been calculated and consequently the fuel consumption. 


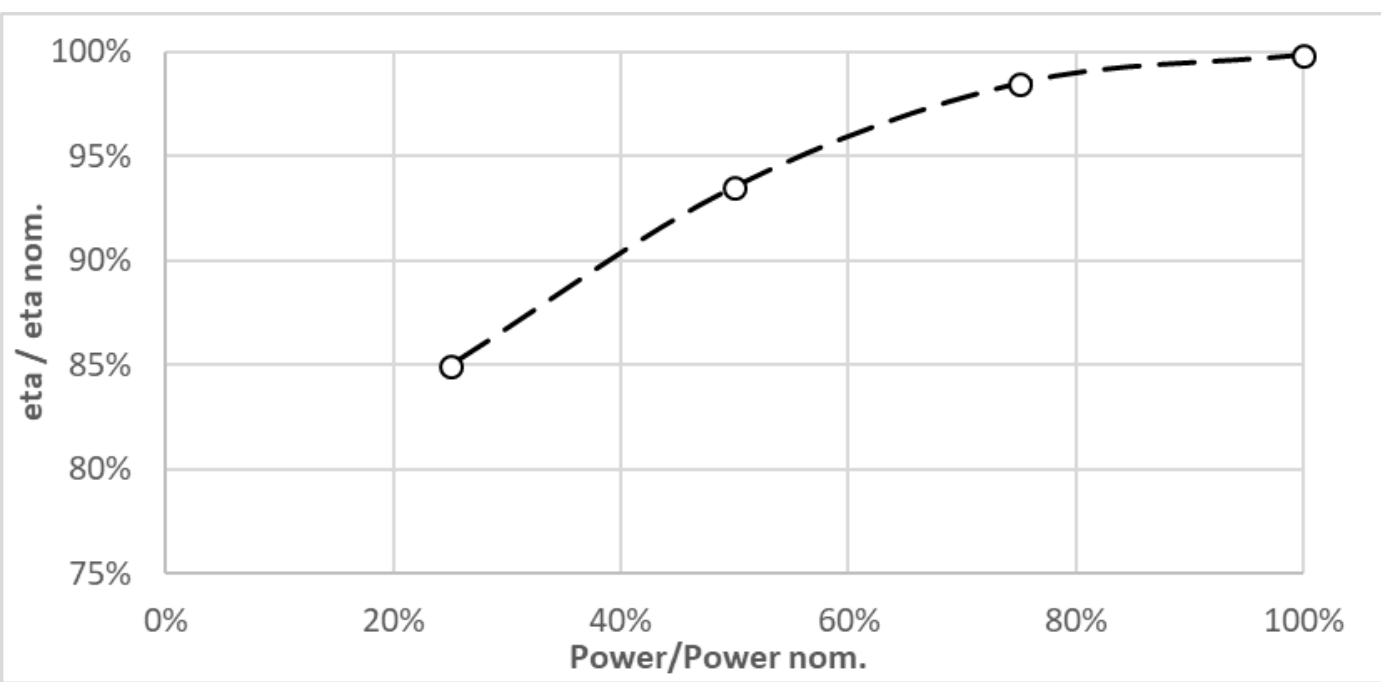

Figure 2 Coal-fired power plant off-design curve [21]

In Figure 3, the weekly profile of the reference plant is reported. Because of the increasing RES penetration on the national grid, the fossil-fueled power plant is forced to operate in discontinuous conditions during the day; in particular, it is forced to be shut down during weekend days when the energy demand is lower, and the RES are able to cover most of the demand. As consequence, the total operating hours of the coal-fired power plant decreases significantly with a strong negative effect on the average annual electrical efficiency. In the case under investigation, the weekly profile reported in Figure 3 is replicated for 51 weeks per year with one week of out of operation for scheduled maintenance.

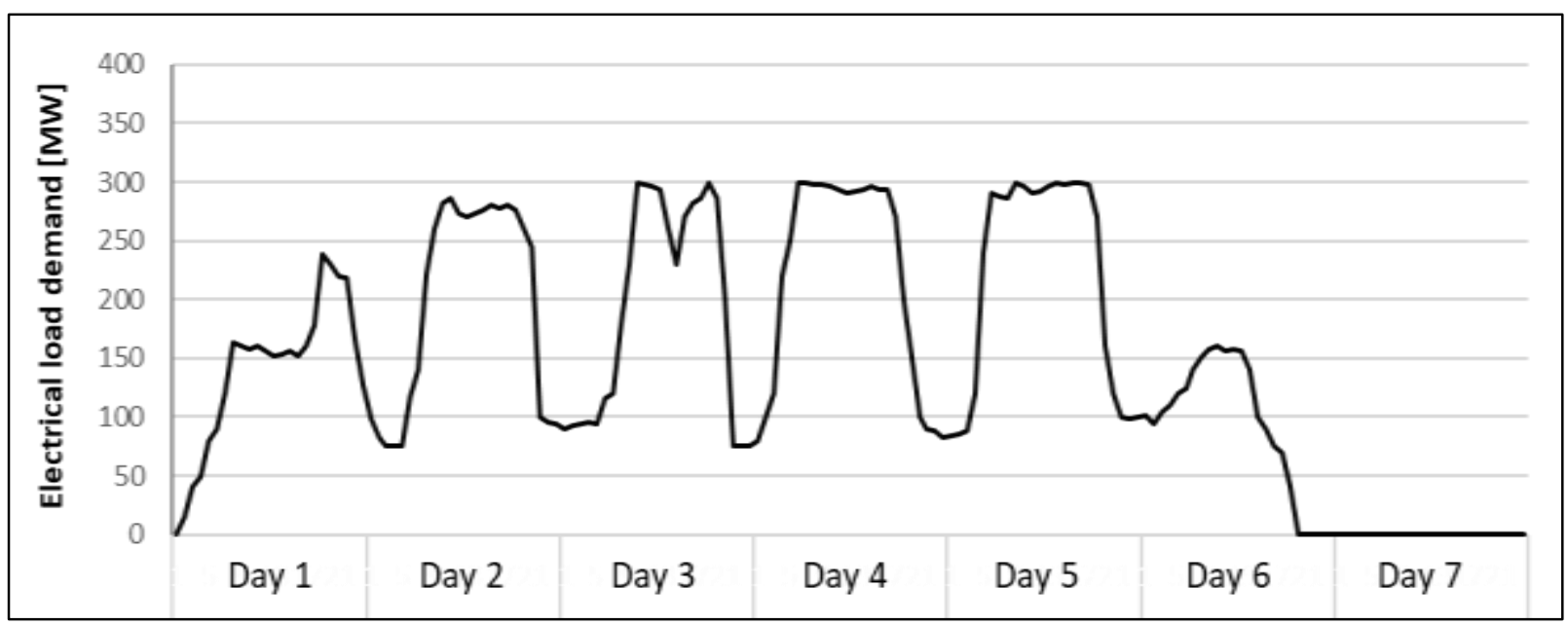

Figure 3 Coal-fired power plant weekly profile

\section{Carbon Capture Unit (CCS)}

The carbon capture technology considered in present work is an amine-based absorption system using a $30 \%$ MEA solvent. The $\mathrm{CO}_{2}$ capture rate is assumed equal to $90 \%$ and the thermal and electrical energy consumptions are assumed equal to 
[21]. In Table 2, the main technical assumptions related to the CCS are reported.

Table 2 CCS Main technical assumption [24][25][26][27]

$\begin{array}{lrl}\text { CO2 capture rate } & 90 \% & - \\ \text { Thermal energy requirement } & 2.9 & \mathrm{GJ} / \text { ton } \\ \text { Electrical energy requirement } & 100 & \mathrm{kWh} / \mathrm{ton} \\ \text { SOLVENT } & 30 \% & \mathrm{MEA} \\ \text { Amine lean solvent loading } & 0.28 & \mathrm{~mol} \mathrm{CO} / \mathrm{mol} \mathrm{MEA} \\ \text { Solvent rate } & 25 & \mathrm{~m} 3 / \text { ton } \mathrm{CO}_{2} \\ \text { MEA LOSS } & 0.5 & \mathrm{kgMEA} / \text { ton } \mathrm{CO}_{2}\end{array}$

In the following section, the three different plant configurations are analyzed in detail, comparing them to the reference case

(CASE 1) of a coal-fired power plant. The results are compared in terms of energy (throughout average efficiency, fuel consumption and equivalent operating hours), of global pollutant emissions (represented by $\mathrm{CO}_{2}$ ) and in economic terms (represented by COE), in order to determine the best configuration.

\section{Power to fuel (PtF) plant - Methanol synthesis unit}

The PtF plant is composed by a $100 \mathrm{MW}$ system of PEM electrolyzers, producing oxygen and hydrogen, and a methanol synthesis unit with a capacity of about $84 \mathrm{kton} / \mathrm{year}$ of methanol.

The scheme of the PtF section is shown in Figure 4. The hydrogen and the carbon dioxide captured from the exhaust gas of the power plant, are sent to the synthesis unit for the methanol production. The PtF plant is electrically connected to the power plant. The methanol reactor is assumed to operate constantly at nominal conditions throughout the whole year; therefore, when electrical energy from the power plant is not available, the required energy is purchased from the grid at industrial market price.

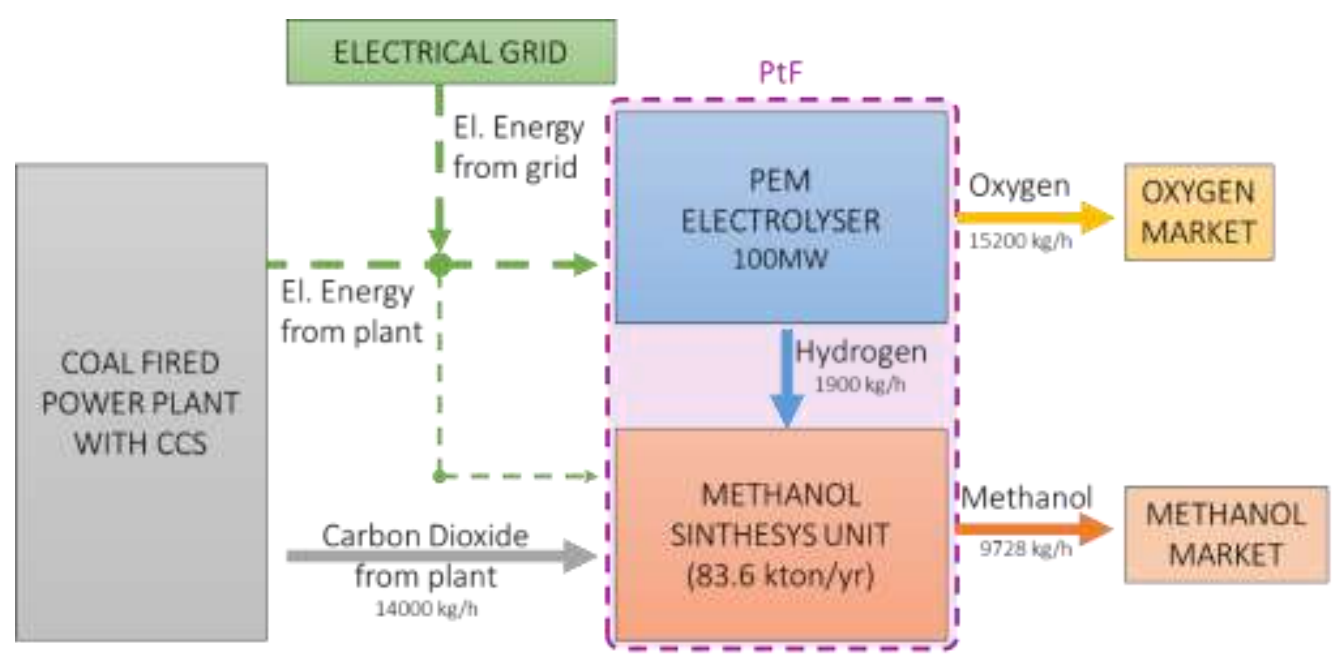

Figure 4: PtF plant integration 
The PtF plant is mainly composed by $100 \mathrm{MW}$ PEM electrolyzers system operating at 30 bar and with a specific energy consumption of about $4.7 \mathrm{kWh} / \mathrm{Nm}^{3}$ and a methanol synthesis unit, operating at 80 bar, which includes also the compression trains for $\mathrm{CO}_{2}$ and Hydrogen. PEM electrolysers are based on the solid polymer electrolyte concept for water electrolysis. The technology is less mature than alkaline electrolysers and mostly used for small-scale applications [28], even if several producers have recently started to develop larger size units (>1 MW for module). Key advantages are high power density and cell efficiency, provision of highly compressed and pure hydrogen and oxygen, fast response and low start-up time. The main drawbacks are the shorter lifetime and the higher costs, due to platinum catalyst and to expensive materials for membrane. However, costs have reduced significantly in the last years and the future developments are aimed at lowering them further. In Table 3, the main technical assumptions for both the electrolyzers and the methanol synthesis unit are reported.

Table 3: PtF plant [29][30][31][32]

\begin{tabular}{|ll|}
\hline 100 MW PEM Electrolysers & \\
Electrical consumption & $4.7 \mathrm{kWh} / \mathrm{Nm}^{3} \mathrm{di} \mathrm{H}_{2}$ \\
Pressure & $30 \mathrm{bar}$ \\
Efficiency & $75 \%$ \\
PEM availability & $98 \%$ \\
Methanol Unit & \\
Working Pressure & $80 \mathrm{bar}$ \\
Temperature & $240{ }^{\circ} \mathrm{C}$ \\
Recirculation factor of unreacted syngas & 0.85 \\
Conversion efficiency & $96 \%$ \\
Molar $\mathrm{H}_{2}: \mathrm{CO}_{2}$ ratio & $3: 1$ \\
\hline
\end{tabular}

\subsection{Economic assumption for the Assessment of the Cost of Electricity}

174 The COE is used as a term of comparison for the different case studies evaluation. It is defined as the average annual value of the electrical energy production cost and it is calculated as the ratio between the annual electrical energy production and the annual overall cost comprising the TCC annual fraction, the annual fixed costs, and the annual variable costs.

$$
\mathrm{COE}=\frac{\text { Annual Overall Cost }}{\text { Annual el. energy production }}[€ / M W h]
$$
In order to perform the economic analysis of the system, the fixed and variable costs of the power plant, the CCS system, and 179 the PtF plant respectively have to be evaluated.

180 Following the technical results, the different cases are evaluated and compared from the economic point of view. For each 181 case, fixed costs, variable costs and Cost Of Electricity (COE) are calculated.

\section{Fixed costs}


Fixed costs refer to the capital cost, installation cost, and the fixed O\&M costs of the Coal Fired Power Plant (CFPP), the CCS, and the PtF respectively. In Table 4, the capital cost functions used in the present study are reported. All the cost functions are the result of the extrapolation of several literature data updated to 2017 with the CEPCl coefficient.

The cost functions for the power plant and the CCS system reference to the total capital cost (TCC) and include both the purchased equipment cost and the installation cost. Instead, the cost functions of the electrolyzer and the methanol unit refer to the purchased equipment costs. The TCC of the PtF plant is calculated considering a correction factor on PEC value, estimated as 2.22 [33], in order to take into proper account the additional costs related to installation and plant commissioning.

Table 4 Capital cost functions [34][35][36][37][38][39]

\begin{tabular}{|l|c|}
\hline Coal-fired Power Plant & $T C C_{C F P P}=20.67 * 10^{6} *\left(P_{\text {inst }[M W]}\right)^{0.6}$ \\
\hline Carbon Capture Unit & $T C C_{C C U}=4.1811 * 10^{6} *\left(M_{C O 2_{\text {nom }}[\text { ton } / \mathrm{h}]}\right)^{0.7}$ \\
\hline PEM electrolyzer & $C C_{P E M}=1.2 \cdot 10^{6} * P[M W]^{0.85}$ \\
\hline Methanol production unit & $C C_{M e O H}=20.4 \cdot 10^{3} * M i n\left[\frac{\mathrm{kg}}{\mathrm{h}}\right]^{0.65}$ \\
\hline
\end{tabular}

As result, for the $300 \mathrm{MW}$ coal-fired power plant under investigation, the specific capital cost of the plant with and without the CCS resulted equal to about $2111 € / \mathrm{kW}_{\text {inst }}$ and $2885 € / \mathrm{kW}$ inst, respectively.

The fixed O\&M cost refers to costs for the plant operating that are independent by the running hours but are a function of the

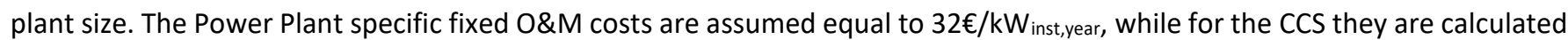
as the $10 \%$ of the TCC[37].

\section{Variable costs}

Variable costs are related to the operation and maintenance of the power plant (with and without the CCS) and of the PtF plant. For the power plant, they are made of the consumed fuel costs, the variable O\&M costs (that depend on the operating hours and are expressed as a function of produced energy), the start-up costs (that are distinguished between cold and warm start-ups), and the costs of the $\mathrm{CO}_{2}$ emission that are evaluated as the average of the 2017 and 2018 EUA values [40].

\section{Plant lifetime}

In order to calculate annual costs, the TCC of the CFPP, of the CCS, and of the PtF are divided by the respective plant lifetimes, which are assumed equal to 40 years, 20 years and 20 years respectively, according to literature data.

In Table 5, the main economic assumptions for the power plant and the CCS are summarized.

Table 5: Main economic assumptions for CFPP and CCS [37-49] 


\begin{tabular}{|c|c|c|c|}
\hline Plant lifetime & 40 & years & \\
\hline CCS lifetime & 20 & years & \\
\hline \multicolumn{4}{|l|}{ Capital \& Installation Costs } \\
\hline Coal Plant w/o CCS & 2111 & $€ / k W \_$inst & \\
\hline Coal Plant w CCS & 2885 & $€ / k W \_$inst & $+37 \%$ \\
\hline \multicolumn{4}{|l|}{ Fixed Costs } \\
\hline Fixed O\&M cost & 32 & $€ / k W$ year & \\
\hline Fixed CCS cost & $10 \%$ & $\% \mathrm{TCl}_{\mathrm{ccs}}$ & \\
\hline \multicolumn{4}{|l|}{ Variable Costs } \\
\hline Fuel cost & 12 & $€ / M W h$ & \\
\hline Variable O\&M cost w/o CCS & 3.5 & $€ / M W h$ & \\
\hline Variable O\&M cost w CCS & 8 & $€ / M W h$ & $+56 \%$ \\
\hline COLD start-up (>120h of standstill) & 280 & $€ / M W$ & \\
\hline WARM Start-up (24-120h of standstill) & 160 & $€ / \mathrm{MW}$ & \\
\hline $\mathrm{CO} 2$ emission cost & 10 & $€ /$ ton & \\
\hline
\end{tabular}

208 3. RESULTS

$209 \quad 3.1$ Part I: Technical analysis results

210 CASE 1 - Reference case

211 The Coal plant capacity factor results lower than $50 \%$ and the average efficiency is about $43 \%$ ( 2 percentage p.ts lower than

212 the nominal values). The weekly-shut down results in 50 warm start-ups (24-120h of standstill) while the scheduled 213 maintenance causes one cold start-up ( $>120 \mathrm{~h}$ of standstill). The "warm" and "cold" terms refer to the metal temperature of 214 the turbine and it depends on the number of hours of the stand still period between two operating periods. The longer the 215 standstill phase and the lower the system temperature, the higher the cost of the start-up since the start-up fuel consumption 216 increases, the auxiliary power demand increases and also the maintenance costs grow because the thermal cycle strongly 217 impact on the wear and tear of the components [43]. The operating cost associated to these procedures were considered in 218 the economic assessment (Part II). In Table 4, the main performance data related to the reference plant are reported.

Table 6: coal power plant main results

\begin{tabular}{|lrl|}
\hline Energy production & 1302.72 & GWh \\
Tot fuel consumed & 3015.13 & $\mathrm{GWh}$ \\
Avg. efficiency & $43 \%$ & $\%$ \\
Capacity factor & $49.8 \%$ & $\%$ \\
Eq. Operating hours & 4343 & $\mathrm{~h}$ \\
Cold start-up (>120h of standstill) & 1 & $\mathrm{n}$. \\
Warm Start-up (24-120h of & 50 & $\mathrm{n}$. \\
standstill) & & \\
CO2 emission & $1,055,296$ & ton/yr \\
CO2 emission rate & 0.81 & Ton CO2/MWhe \\
\hline
\end{tabular}




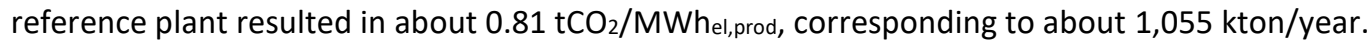

The CCS integration entails a significant reduction in terms of nominal net power output (from $300 \mathrm{MW}$ to $245 \mathrm{MW}$, about $18 \%$ ) and in the nominal efficiency (from $45 \%$ to $37 \%$, about 8 percentage points). In order to satisfy the energy demand of the CCS plant, part of the working steam is spilled from the coal plant, resulting in a reduction of the amount of electrical energy that can be produced and sold to the grid. If on the one hand, the integration of a CCS in an existing coal plant reduces the maximum power output, on the other hand, it allows for a reduction of the minimum electrical load (around $45 \mathrm{MW}$ ) of the plant and, hence, increases the plant flexibility.

Figure 5 reports the comparison between the traditional coal power plant (CASE 1) and the coal power plant equipped with CCS (CASE 2). The presence of CCS leads to a decrease in terms of energy efficiency: electrical energy production decreases of about $8 \%$ on yearly basis, while primary energy input in terms of fuel consumption is about $10 \%$ higher than in the traditional case. On the other hand, $\mathrm{CO}_{2}$ emissions are considerably reduced, allowing for a consequent saving in terms of emissions.

\section{CASE 3 (coal plant $w / o C C S+M e O H$ plant)}

CASE 3 considers the coal plant connected with the PtF plant: this study case highlights just the effect of the increase in the power plant operating hours and can be considered as a basis for comparison with Case 4: for this reason, the $\mathrm{CO}_{2}$ required by the PtF plant operation was not taken into account. The analysis shows an average efficiency of $44 \%$ (an increase of 1 percentage point with respect to case 1 ) due to an increase of equivalent operating hours from 4343 up to 6501 . Consequently, fuel consumption and $\mathrm{CO}_{2}$ emissions increase as well. 


\section{CASE 4 (coal plant with CCS $+\mathrm{MeOH}$ plant)}

Figure 6 shows the operational management of the coal-fired power plant, equipped with CCS, in case of coupling with the PtF plant for methanol synthesis: the maximum power output of the plant is $245 \mathrm{MW}$ due to the CCS integration; the dashed area represents the amount of electrical energy produced by the coal plant and employed to feed the electrolyzers and the other components (i.e. CCS, compressors) included in the PtF plant. Coupling the two plants represents some advantages in terms of management of the coal plant: first, weekend shutdowns and related costs are avoided; moreover, the global average efficiency increases of more than 1 percentage point.

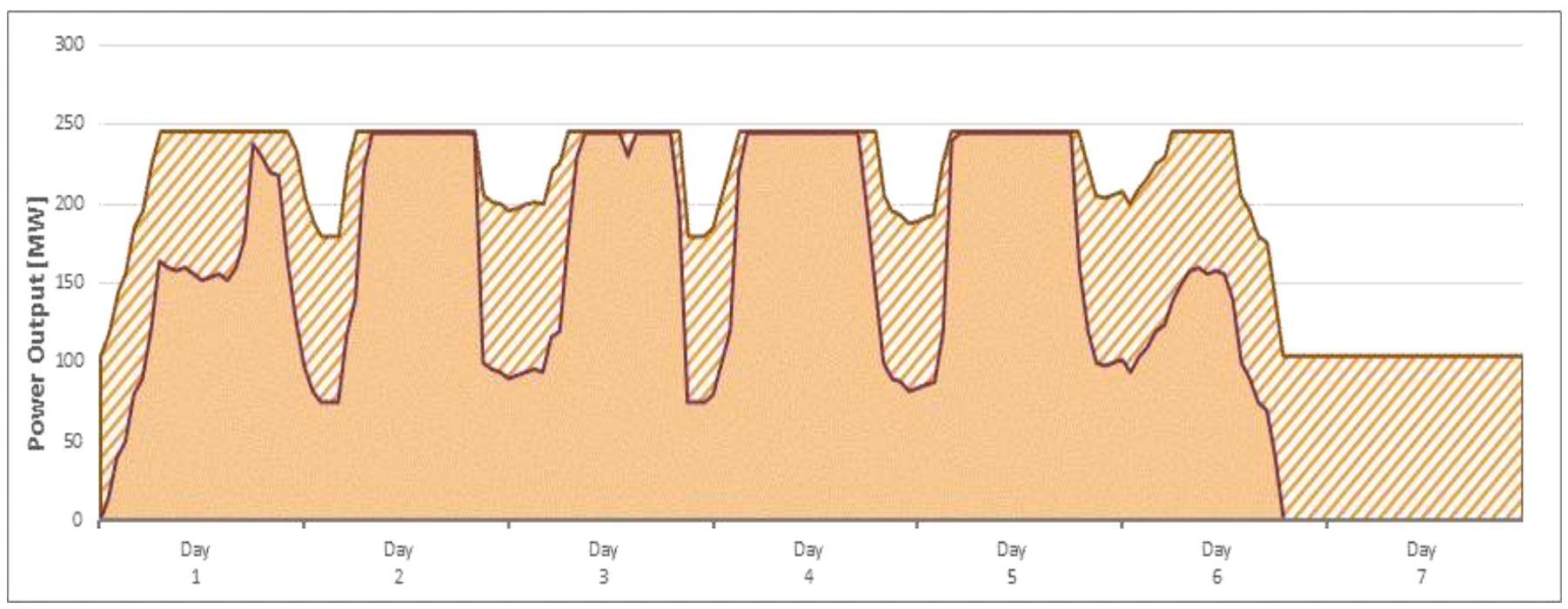

Figure 6: Week operational management of the case 4 (coal plant with CCS + MeOH plant)

The annual energy production increases up to $1756 \mathrm{GWh}$ and the plant operating hours increased up to 7165 hours $(+47 \%$ compared to CASE 2), corresponding to a capacity factor around $82 \%$.

On the base of the above-reported assumptions, the total amount of produced methanol results 83.6 kton/year, with a carbon dioxide utilization of $119.8 \mathrm{kton} /$ year and a total energy consumption of $900 \mathrm{GWh} /$ year $(62 \%$ from the power plant and $38 \%$ purchased from the grid). In addition, the PtF plant produces 130.6 kton/year of Oxygen that can be sold to industrial users. In Figure 7, the electrical energy management of the PtF plant is reported. 


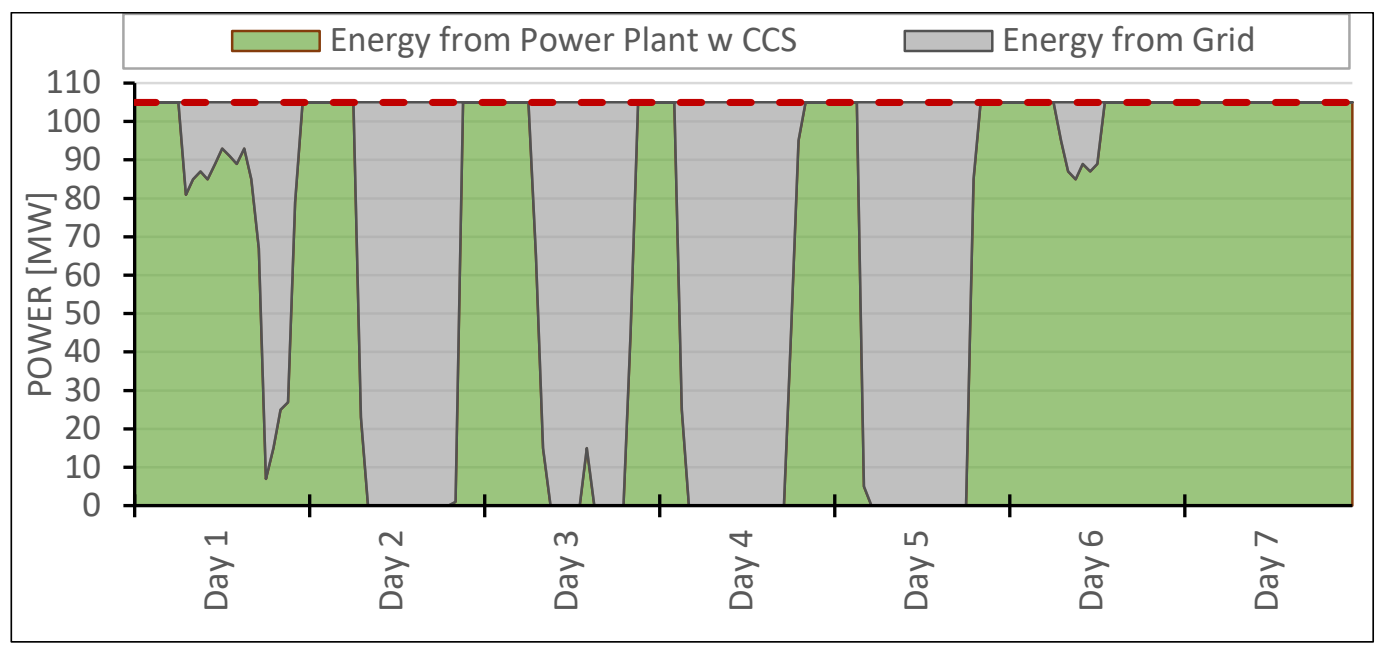

Figure 7 PtF plant electrical energy management

\section{Case comparison}

Figure 8 reports a comparison from both the energy and the environmental point of views of three configurations with the reference case, represented by the coal-fired power plant without CCS. In particular, the percentage variation of different parameters, such as annual average efficiency, $\mathrm{CO}_{2}$ emissions, fuel consumption and annual electrical energy production, are reported for case 2 (coal plant with CCS), case 3 (coal plant with only methanol plant), and case 4 (coal plant with CCS and methanol plant). The configuration of the case 2 results the worst option from the energy standpoint, leading to lower efficiencies and electrical energy production and to higher fuel consumption; on the other hand, it assures a significant decrease $(-89 \%)$ in terms of $\mathrm{CO}_{2}$ emissions. Solution 3 (coal plant coupled to PtF plant) guarantees the best results in terms of energy production, efficiency and capacity factor, but it also implies an increase of $48 \%$ in terms of $\mathrm{CO}_{2}$ emissions, due to fuel consumption increase. The case 4 (including CCS and PtF plant coupled to the coal plant) allows for a significant reduction of

$273 \mathrm{CO}_{2}$ emissions ( $-84 \%$ compared to reference case) and for an increase of energy production and therefore of the capacity factor (+35\%); the annual average efficiency decreases compared to the reference case, but less than in case 2 .

\begin{tabular}{|l|c|c|c|c|}
\multicolumn{5}{c}{ Table 7: coal power plant main results } \\
\cline { 2 - 5 } \multicolumn{1}{|c|}{} & CASE 1 (Ret. Case) & CASE 2 & CASE 3 & CASE 4 \\
\hline Nominal Power [MW] & 300 & 245 & 300 & 245 \\
Energy production [GWh] & 1,303 & 1,195 & 1,950 & 1,756 \\
Tot fuel consumed [GWh] & 3,015 & 3,356 & 4,470 & 4,786 \\
Avg. Efficiency [\%] & $43 \%$ & $36 \%$ & $44 \%$ & $37 \%$ \\
Capacity factor [\%] & $50 \%$ & $45 \%$ & $74 \%$ & $67 \%$ \\
CO2 emission [kton/Yr] & 1,055 & 118 & 1,565 & 168 \\
CO2 captured [kton/yr] & - & 1,057 & - & 1,508 \\
CO2 Avoided [kton/yr] & - & 937 & - & 1,397 \\
\hline
\end{tabular}




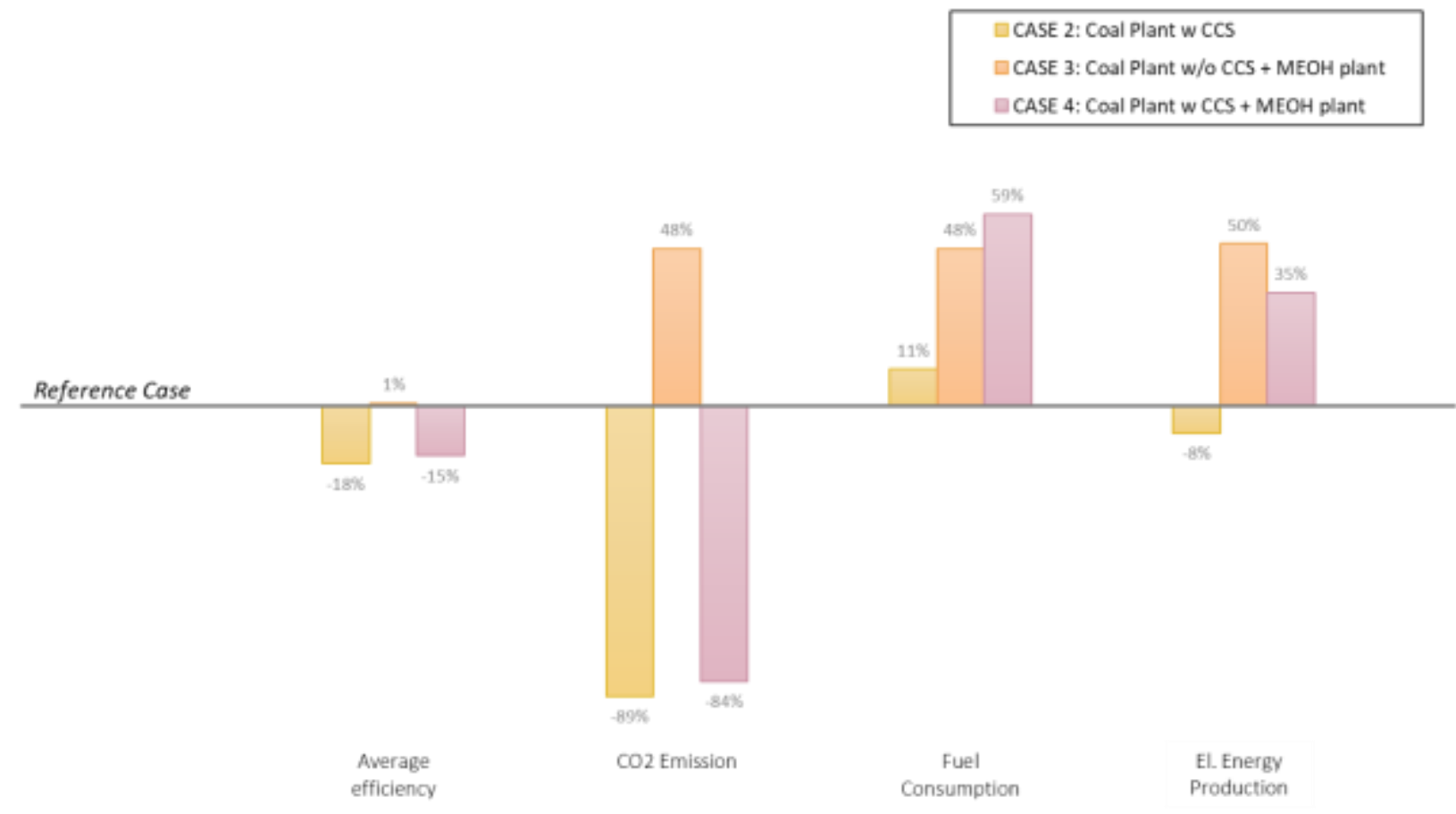

Figure 8: Energy and environmental comparison, referred to CASE 1

\subsection{Part II: COE assessment results}

Figure 9 shows the costs' distribution for the four cases. In case 1 (reference CFPP), the overall annual costs (including both fixed and variable costs) are about 79M€: the most important voice is represented by fuel costs (46\%), followed by annual plant costs (20\%); it is worth noting that $\mathrm{CO}_{2}$ costs are not negligible (13\%), since the high amount of emissions. The warm and cold start-up costs contribution is about $3 \%$, but, even if their direct economic impact is not so relevant, they can lead to a reduction of plant lifetime, neglected in this analysis; moreover, a cold start-up implies critical aspects in terms of management, since large size coal-fired power plants are characterized by a considerable thermal inertia [54]. In case 2 (CFPP and CCS integration), the overall annual costs increase up to around 92M€ (14\%) due to the installation of the CCS that impact on both the fixed capital cost (purchase and installation) and the variable costs (O\&M and fuel). On the other side, the cost of the $\mathrm{CO}_{2}$ allowances decreases by about $89 \%$, with a saving of around $9.3 \mathrm{M} €$. 


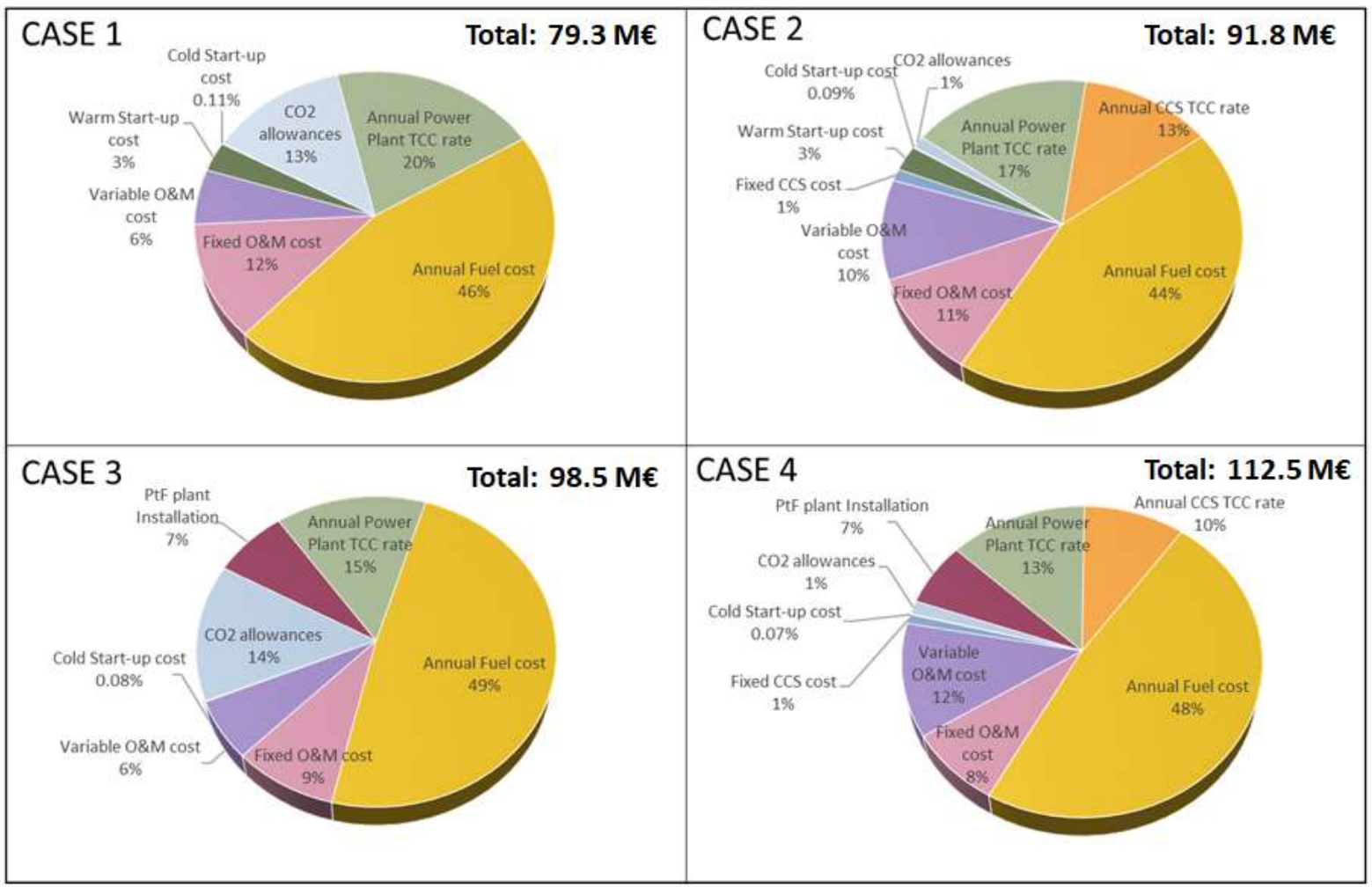

Figure 9: Annual fixed and variable cost breakdown for case 1 (reference coal-fired power plant), case 2 (coalfired plant and CCS integration), case 3 (coal-fired plant and PtF integration), case 4 (coal-fired plant and CCS - PtF integration)

As regards the power to fuel plant with a capacity of about 84 ton/yr of produced methanol, purchased equipment costs of the electrolyzers and of the $\mathrm{MeOH}$ synthesis unit are about $60.4 \mathrm{M} €$ and $11 \mathrm{M} €$, respectively. The annual rate of total capital costs (including the purchase equipment cost and the installation) results equal to about $8 \mathrm{M} €$.

In order to compare the different cases under analysis from the economic point of view, the COE is chosen as term of comparison. Figure 10 reports the comparison between the reference case and the other three configurations in terms of COE and total annual $\mathrm{CO}_{2}$ emission.

The effects of the installation of a CCS unit in the CFPP under analysis are evident: the CCS installation leads to an increase in terms of investment and O\&M costs. The resulting COE for case 2 is about $21 \%$ higher than the one of the reference case (from $61 € / \mathrm{MWh}$ to $77 € / \mathrm{MWh})$. Considering the actual value of the ETS $\mathrm{CO}_{2}$ emission allowances cost (10 $€ /$ ton), the reduction in terms of $\mathrm{CO}_{2}$ taxation is not sufficient to balance the above-mentioned increased costs. In a similar way, comparing the case 3 and case 4 , the COE increases of about $19.6 \%$ (from 56 to $67 € / \mathrm{MWh}$ ).

The integration of the electrical demand of a PtF plant for MeOH synthesis allows for an increase in terms of plant's capacity factor and operating hours, as shown in the previous section (Figure 5). Thus, the contribution of the investment cost on the COE is reduced and the COE gets lower as well. 
The effect of the capacity factor increase is highlighted comparing the reference case and case 3: the COE decreases of $8 \%$, from 61 to $56 € / \mathrm{MWh}$. In a similar way, comparing case 2 and case 4 , the COE decreases by about $13 \%$ (from 77 to $67 € / \mathrm{MWh}$ ). It is worth noting that the installation of the PtF plant affects the COE for only $6 \%$.

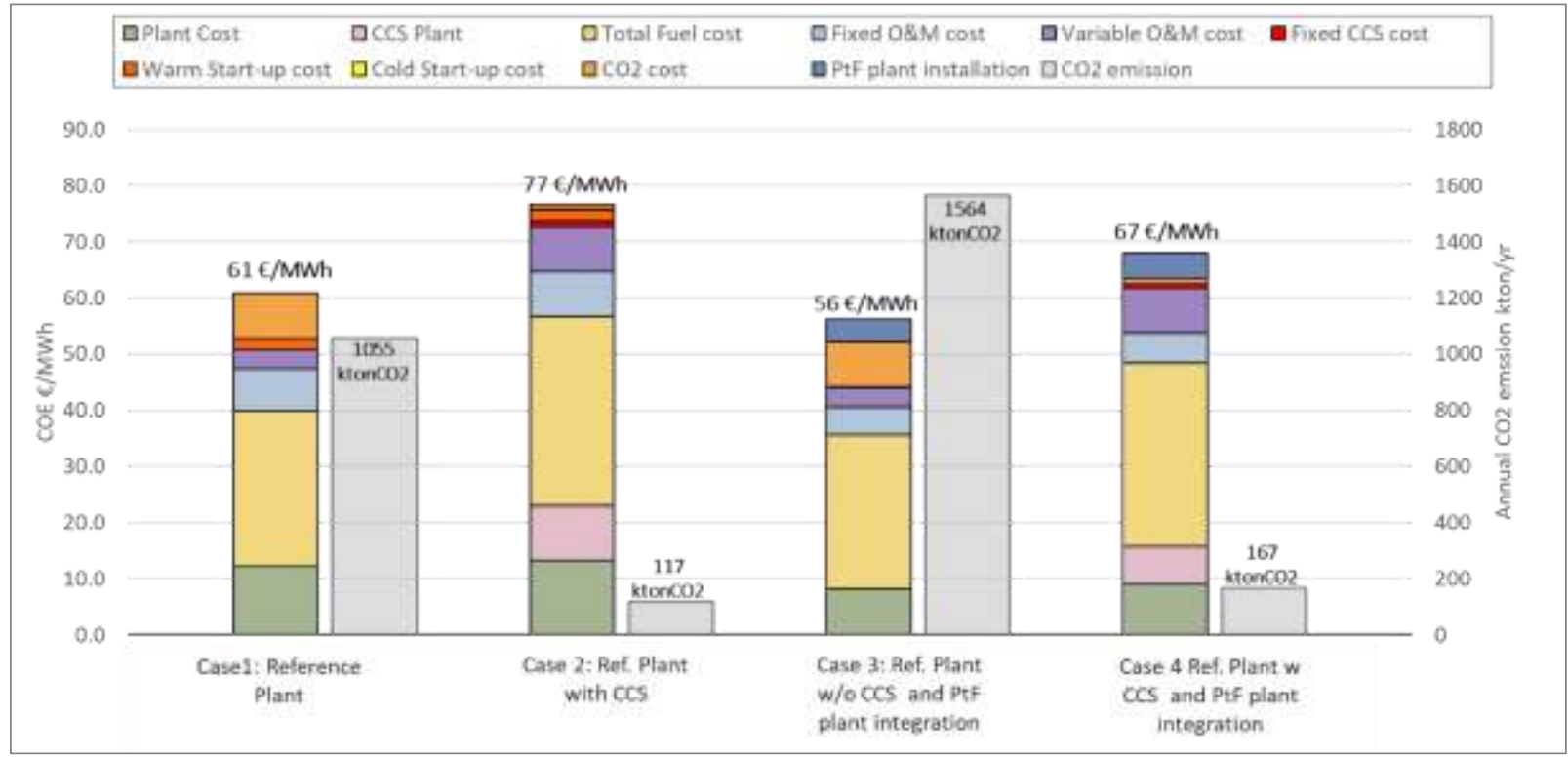

Figure 10: Economic comparison in terms of Cost Of Electricity (COE)

The best solution from the economic standpoint seems to be the case 3 (Coal plant + PtF plant without CCS) showing the lowest $\mathrm{COE}(56 € / \mathrm{MWh})$. Nevertheless, this solution presents also the highest annual $\mathrm{CO}_{2}$ emissions value (about $\left.1564 \mathrm{kton}\right)$, on the other side without CCS the $\mathrm{CO}_{2}$ necessary would not be available. Whereas, in case 4 , the $\mathrm{COE}$ increase is compensated by a strong reduction in the $\mathrm{CO}_{2}$ emissions (about 90\%). Considering the evolution of the ETS system for $\mathrm{CO}_{2}$ emissions, in the next section a further analysis is performed, in order to evaluate a next future scenario

\section{$\underline{\text { ETS Carbon price in future scenarios }}$}

The results presented in the previous section show a not negligible contribution of the voice of cost related to $\mathrm{CO}_{2}$ emissions: in fact, coal-fired power plants are characterized by important emission of this kind, thus by quite significant costs. The calculations in the previous section are performed considering the average $\mathrm{CO}_{2}$ emission cost between 2017 and 2018 , as reported by the ETS [1]. However, it is worth observing that this cost is expected to increase quite significantly in the next years, considering the European policies of decarbonization for the future (after 2020). A study of the ETS reports different forecast scenarios about the $\mathrm{CO}_{2}$ cost trend up to 2050. Based on this a sensitivity analysis is performed, analyzing the impact of the $\mathrm{CO}_{2}$ emission cost on the COE in the next future. Figure 11 reports the COE values for each analyzed cases, in different timeframe: it clearly shows how the configurations without CCS would be no more feasible in the future, because of higher costs related to $\mathrm{CO}_{2}$ emissions. In particular, in case of an average cost of $31 € /$ ton (medium scenario for 2030), the configuration 
with CCS and PtF plant would be more attractive from an economic standpoint. The break event point for which the cases 1 and 4 and 3 and 4 have the same $\mathrm{COE}$ value, corresponds to a $\mathrm{CO}_{2}$ cost of about $18 € /$ ton and $25 € /$ ton, respectively.

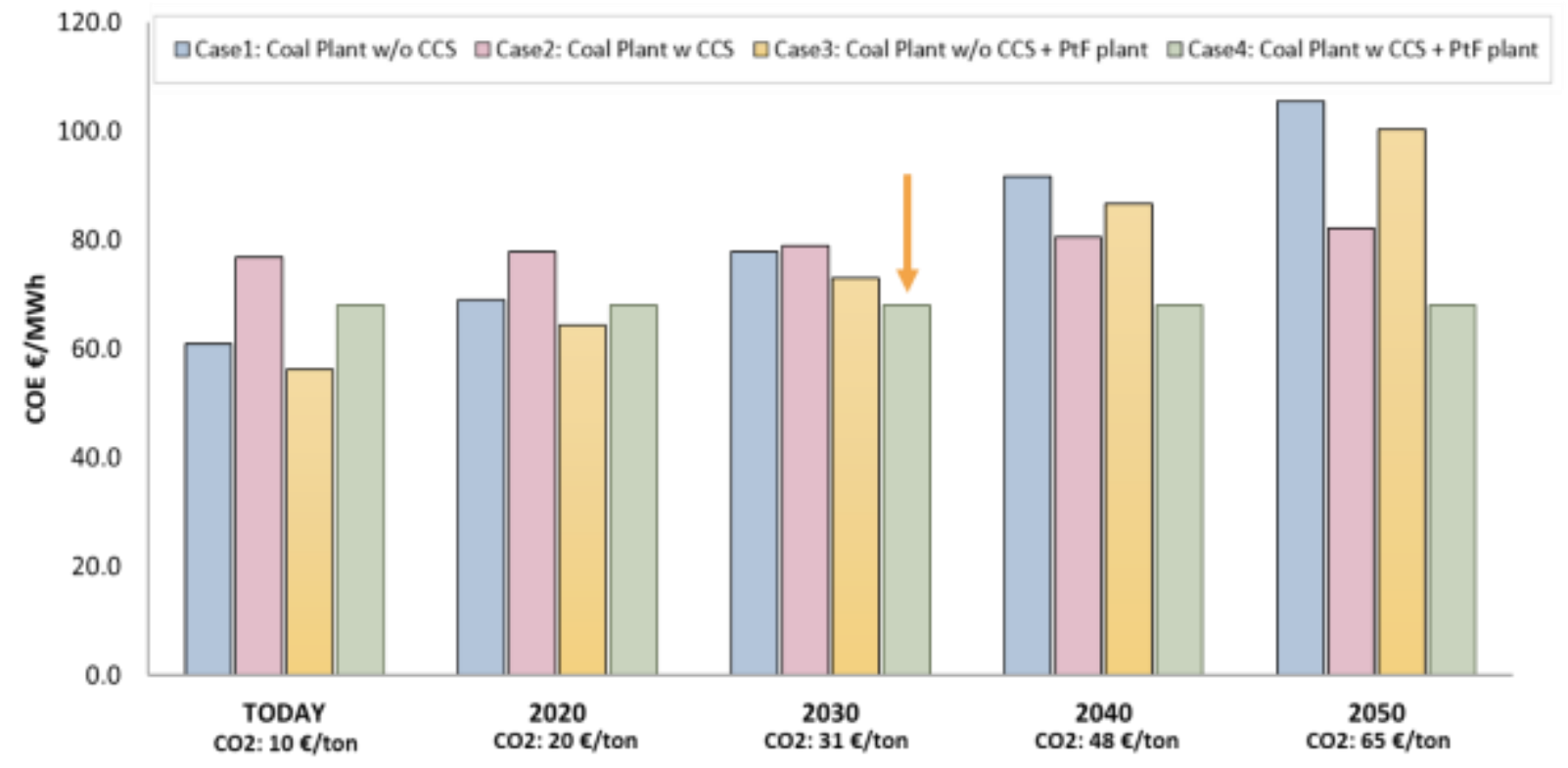

Figure 11: Economic comparison in terms of Cost Of Electricity (COE)

\section{POWER TO FUEL PLANT ECONOMIC FEASIBILITY STUDY AND SENSITIVITY ANALYSIS} $€ /$ ton, which is the minimum value of high purity oxygen for medical application[12][56];

- Carbon dioxide cost: the $\mathrm{CO}_{2}$ necessary for the methanol production is purchased from the CFPP at the sequestration cost (15 €/ton);

- $\quad$ Oxygen selling price: the oxygen co-produced by the electrolyzer is assumed to be sold at an estimated price of 150 
The aim of the economic analysis is to determine the methanol production cost (MPC), in order to evaluate if the investigated solution can be viable from the economic standpoint. Two different MPCs are calculated: the first one does not consider additional revenues from $\mathrm{O}_{2}$ sale, while the second one is corrected taking into account the revenues associated with $\mathrm{O}_{2}$ :

$$
M P C_{O 2 \text { sale }}=\frac{\text { annual fixed costs }+ \text { annual variable costs }-\mathrm{O}_{2} \text { sale revenues }}{\text { annual methanol production }} \quad[€ / \text { ton }]
$$

Table 7: economic results for PtF plant

\begin{tabular}{|lr|}
\hline Purchased equipment cost & $71.3 \mathrm{M} €$ \\
Methanol unit & $10.9 \mathrm{M} €$ \\
Electrolyzers & $60.4 \mathrm{M} €$ \\
Total Capital Investment & $158.3 \mathrm{M} €$ \\
& \\
PtF plant lifetime & 20 years \\
& \\
Fixed Annual Costs & $\mathbf{8} \mathbf{M} €$ \\
Annual Variable Costs & $\mathbf{6 1} \mathbf{~ M €}$ \\
$\quad$ Electrical energy from Plant & $35.3 \mathrm{M} €$ \\
$\quad$ Electrical energy from Grid & $23.8 \mathrm{M} €$ \\
CO ${ }_{2}$ purchased from plant & $1.8 \mathrm{M} €$ \\
& \\
Annual Methanol production & $\mathbf{8 3 . 6} \mathbf{~ k t o n} / \mathrm{yr}$ \\
Methanol production cost & $\mathbf{8 2 3} € /$ ton \\
Methanol Production Cost $\mathbf{O}_{\mathbf{2}}$ sale & $\mathbf{5 8 9} € /$ ton \\
\hline
\end{tabular}

The resulting MPC is around $823 € /$ ton; considering selling the oxygen at $150 € /$ ton, it decreases by about $30 \%$. Nevertheless, considering that the actual methanol market price is $400-450 € /$ ton, the investigated solution does not seem economically viable from the PtF standpoint in the actual economic scenario. On the other hand, the advantages from the environmental point of view are not negligible: the PtF allows for an increase in the average efficiency of the power plant and recycling about 120,000 ton/yr of $\mathrm{CO}_{2}$.

\section{$\underline{\text { Sensitivity Analysis }}$}

In order to investigate the economic viability of PtF in some possible short-to-midterm future scenarios, a sensitivity analysis is performed considering the variation of some economic parameters that are likely to change in the next future. In particular: 
- Methanol selling price: considering the use of the methanol as a fuel in automotive transportation, it is reasonable to assume that its market price at refueling station will be higher than the actual market price (around $400 € /$ ton as 2018 average [57]). A range of variation from 400 up to $1000 € /$ ton is chosen.

- Oxygen selling price: considering the actual price of 150€/ton [12][56]an increment of the actual value up to 200 and $250 € /$ ton is considered.

- El. Energy cost from the grid: in order to take into account different future economic scenarios, a variation of $+/-30$ $€ / \mathrm{MWh}$ compared to the reference value of $70 € / \mathrm{MWh}$ is considered (considered range: $40-100 € / \mathrm{MWh}$ ).

- PEM electrolyzers capital cost: the electrolyzers resulted in the most expensive components, but considering that it is a rather new technology, it seems likely that its development in the next future will lead to a reduction in the production cost. For this reason, a percentage reduction in the PEM electrolyzers capital cost of $30 \%$ up to $50 \%$ is considered.

For each parameters' values combination, the Internal Rate of Return (IRR) is calculated as follow:

$$
I R R=\frac{\text { Annual net cash flow }}{\text { Initial Investment }} \times 100=\frac{1}{P B P} \times 100 \quad[\%]
$$

The IRR is an economic indicator useful to evaluate the economic viability of a plant (at a pre-feasibility level): IRR equal to $10 \%$ is considered the threshold value for the economic viability of the plant. Below, the results of the sensitivity analysis are presented and discussed.

Figure 12 reports a matrix of contour graphs reporting the IRR values as a function of the methanol selling price and the electricity cost for different values of the oxygen selling price and of the percentage reduction in the PEM electrolyzers capital cost. In particular, 4 different areas are outlined: (i) the light blue area corresponding to IRR values greater than $20 \%$; the green area corresponding to IRR values greater than 10\%;(ii) the orange area corresponding to IRR values greater than $5 \%$ and represents the limit for the system viability; (iii)the red area corresponding to IRR values lower than $5 \%$ and the system results not feasible;(iv) in the end, the grey area represents "no-existing area" including the cases where the costs are greater than the revenues.

Thanks to these maps, it is possible to define the minimum methanol selling price that allows a target IRR value to be achieved. For example, for the actual condition, with electricity cost fixed at $70 € / \mathrm{MWh}$ and the oxygen selling price equal to $150 € /$ ton, considering the $100 \%$ of the PEM electrolyzers capital cost, the minimum price of the methanol to achieve the $10 \%$ of IRR is 
about $683 € /$ ton. However, if the capital cost was reduced by $30 \%$ or $50 \%$ (by technological development), the methanol price would decrease to $635 € / \mathrm{MWh}(-7 \%)$ and $603 € / \mathrm{MWh}(-12 \%)$ respectively. On the other hand, for $100 \%$ of PEM electrolysers capital cost and for the same value of the electricity cost from grid (70€/MWh), if the oxygen selling price increased up to 200 or $250 € /$ ton, the minimum methanol selling price would be reduced by $11 \%$ (605 €/ton) and $23 \%$ ( $527 € /$ ton), respectively. Instead, if the electricity cost increased or decreased by $30 € / \mathrm{MWh}(40 € / \mathrm{MWh}$ and $100 € / \mathrm{MWh})$, the MeOH price would be $561 € /$ ton $(-18 \%)$ and $765 € /$ ton $(+18 \%)$, respectively.

The sensitivity analysis showed that the most affecting factor in terms of methanol selling price variation is the electrical energy cost, followed by the oxygen price and the percentage reduction of PEM electrolyzers capital cost; in fact, for a variation of $30 \%$ of these three parameters, the $\mathrm{MeOH}$ price varies in a range of $13 \%, 10 \%$, and $7 \%$.

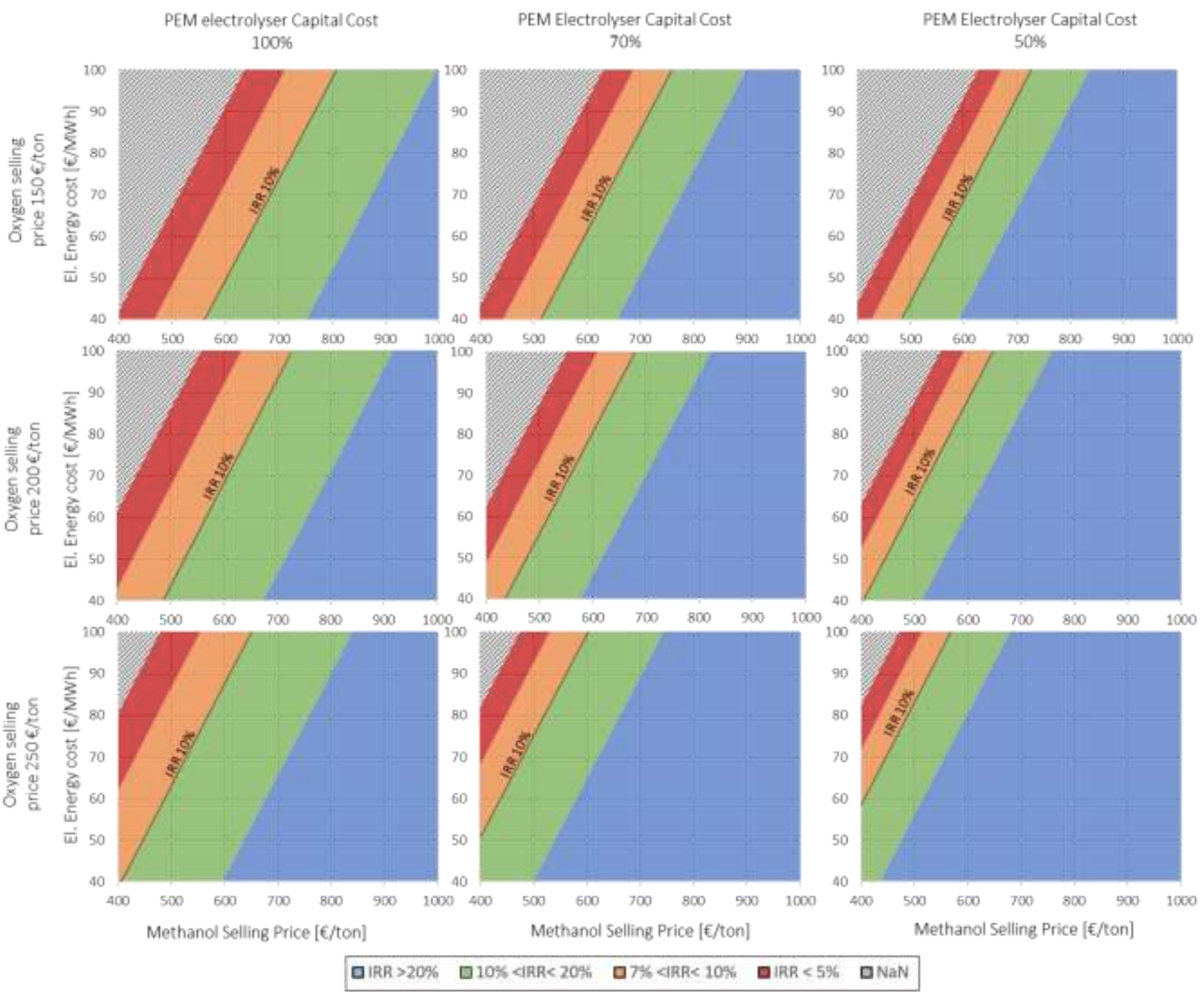




\section{CONCLUSIONS}

In this paper, the integration of a CCS and of a PtF system for methanol production with a coal power plant was investigated from the technical, environmental and economic point of view. The study was carried out in three different steps: firstly, the impact of the CCS installation and PtF plant coupling on the coal power plant performances was analyzed comparing four different configurations. In the second part, the annual cost of electricity (COE) of the different configurations has been assessed and compared; moreover, an analysis considering the forecasted increase of the $\mathrm{CO}_{2}$ allowances cost was investigated to compare the COE of the proposed solutions over the years. Finally, a feasibility economic analysis of the methanol plant was performed, including a sensitivity analysis to evaluate the impact of the most affecting parameters (Purchasing cors $t$ of the electrical energy, selling price of oxygen and methanol, capital cost reduction of PEM Electrolyser driven by a further technology development).

From the obtained results, the following conclusions can be drawn:

- The integration of the PtF plant (cases 3 and 4 ) allows for an increase in terms of the capacity factor (+50\% and $+35 \%$ respectively), avoiding weekend shutdowns and the related operating costs;

- Considering the average energy efficiency of the coal plant, the best solution is represented by case 3 ( $+1 \%$ thanks to the coupling with the PtF plant which increase the coal plant's capacity factor). Cases 2 and 4 show a decrease in terms of average efficiency due to the energy consumption of the CCS (-18\% and $-15 \%$ respectively);

- Considering the environmental aspect, cases 2 and 4 are worthy solutions, thanks to the presence of CCS that allows for a reduction of more than $80 \%$ of $\mathrm{CO}_{2}$ emissions; Instead, the case 3 come out to be the worst option in terms of carbon footprint;

- In terms of COE, the integration of the CCS brings to an increase of about $21 \%$ compared to re Reference case. The lowest COE value is related to the Case 3 ( $56 € / \mathrm{MWh})$; however, considering the expected increase in $\mathrm{CO}_{2}$ emission cost for the next decades, the CCS's presence will be fundamental in order to avoid an increase in terms of COE. Considering the forecasted increase in the cost of EU ETS $\mathrm{CO}_{2}$ emission allowances, since 2025 the price is expected to overcome $25 € /$ ton and case 4 becomes the option with the lowest COE;

- Thanks to the PtF integration, the capacity factor of case 4 increases of about $47 \%$, compared to the case 2 , leading to a decrease in COE of about $13 \%$ (from 77 to $67 € / M W h$ ). It is worth noting that the installation cost of the PtF plant affects the COE of Case 4 for only $6 \%$. 
- As regards the PtF economic feasibility analysis, the results showed that, in the actual scenario, the methanol production cost would be not fully competitive, being higher than the actual market price (around $400 € /$ ton);

- The sensitivity analysis on the IRR of the PtF showed that the most affecting parameter is the purchasing electrical energy cost, followed by the oxygen selling cost and the reduction in the electrolyzer capital cost.

- On the other hand, in a future scenario, considering a potential reduction of electrolyzers' capital cost and of electrical energy cost, methanol production cost would be significantly reduced, up to values very close to the actual market ones. Nevertheless, assuming to employ the so produced methanol for automotive transportation, the target value should be compared to the actual diesel and gasoline costs $(1.27 € / /$ and $1.34 € / /$, respectively in Germany at refuelling station [58]) considering also the benefit in terms of emission related to the methanol combustion in ICE

Finally, it is worth observing that in this study methanol is produced by recycling a significant amount of the carbon dioxide emitted by a coal-fired power plant, avoiding at the same time $\mathrm{CO}_{2}$ emissions related to traditional methods for methanol synthesis.

\section{ACKNOWLEDGMENTS}

Authors gratefully acknowledge the financial support from the 'EU Framework Programme for Research and Innovation Horizon 2020' under the grant agreement No 637016 (MefCO2).

\section{REFERENCES}

[1] https://ec.europa.eu/clima/policies/ets_en access 01/07/2018.

[2] https://ec.europa.eu/energy/en/topics/energy-strategy-and-energy-union/2030-energy-strategy access 31/05/2018

[3] http://ec.europa.eu/eurostat/statistics-explained/index.php?title=Coal_consumption_statistics access 01/07/2018.

[4] Varone A., Ferrari M., "Power to liquid and power to gas: An option for the German Energiewende", Renewable and Sustainable Energy Reviews, 2015 (45), 207-218

[5] www.methanolinstitue.org last access 10/10/2016

[6] Liu H., Wang Z., Xiang S., Wang J., Wagnon S.W., "Methanol-gasoline Dual-fuel Spark Ignition (DFSI) combustion with dualinjection for engine particle number (PN) reduction and fuel economy improvement", Energy, 2015 (89), 1010-1017

[7] Balki M.K., Sayin C., "The effect of compression ratio on the performance, emissions and combustion of an SI (spark ignition) engine fueled with pure ethanol, methanol and unleaded gasoline", Energy, 2014 (71), 194-201.

[8] A. Sorce, A. Greco, L. Magistri, and P. Costamagna, "FDI oriented modeling of an experimental SOFC system, model validation and simulation of faulty states," Appl. Energy, vol. 136, pp. 894-908, Dec. 2014.

[9] Ferrari M.L., Traverso A., Massardo A.F., Smart polygeneration grids: Experimental performance curves of different prime movers. Applied Energy, 162 (2016) 622-630.

[10] Zaccaria V., Tucker D., Traverso A., Transfer function development for SOFC/GT hybrid systems control using cold air bypass. Applied Energy, 165 (2016) 695-706.

[11] X. Li and A. Faghri, "Review and advances of direct methanol fuel cells (DMFCs) part I: Design, fabrication, and testing with high concentration methanol solutions," J. Power Sources, vol. 226, pp. 223-240, Mar. 2013.

[12] Bellotti D., Rivarolo M., Magistri L., Massardo A.F., “Feasibility study of methanol production from different renewable sources and thermo-economic analysis", International Journal of Hydrogen Energy, 2016 (41), 2105-2116. 
473

474

475

476

477

478

479

480

481

482

483

484

485

486

487

488

489

490

491

492

493

494

495

496

497

498

499

500

501

502

503

504

505

506

507

508

509

510

511

512

513

514

515

516

517

518

519

520

521

522

523

524

525

526

[13] Bellotti D., Rivarolo M., Magistri L., Massardo A.F., “Feasibility study of methanol production plant from hydrogen and captured carbon dioxide", Journal of CO2 Utilization, 21 (2017), 132-138.

[14] Pellegrini L., Soave G., Gamba S., Langè S., "Economic analysis of a combined energy-methanol production plant”, Applied Energy, 2011 (88), 4891-4897.

[15] Rivera-Tinoco R., Farran M., Bouallou C., Aupretre F., Valentin S., Millet P., Ngameni J.R., "Investigation of power-tomethanol processes coupling electrolytic hydrogen production and catalytic CO2 reduction", International Journal of Hydrogen Energy, 2016 (41), 4546-4559

[16] G. Leonzio, "State of art and perspectives about the production of methanol, dimethyl ether and syngas by carbon dioxide hydrogenation," J. CO2 Util., vol. 27, pp. 326-354, Oct. 2018.

[17] M. T. Luu, D. Milani, A. Bahadori, and A. Abbas, "A comparative study of CO2 utilization in methanol synthesis with various syngas production technologies," J. CO2 Util., vol. 12, pp. 62-76, Dec. 2015.

[18] Jadhav S.G., Vaidya P.D., Bhanage B.M., Joshi J.B., “Catalytic carbon dioxide hydrogenation to methanol: A review of recent studies", Chemical engineering and Research and Design, 2014 (92), 2557-2567.

[19] Van-Dal ES, Bouallou C. Design and simulation of a methanol production plant from CO2 hydrogenation. J Clean Prod 2013 (57), 38-45.

[20] www.MefCO2.eu last access 10/05/2018

[21] Private communications by Mitsubishi Hitachi Power Systems

[22] H.S. Eggleston, L. Buendia, K. Miwa, T. Ngara, and K. Tanabe (eds). "2006 IPCC Guidelines for National Greenhouse Gas Inventories", The National Greenhouse Gas Inventories Programme, 2006.

[23] F. Ess, F. Peter, and F. Klummp, “Agora Energiewende (2017): Flexibility in thermal power plants - With a focus on existing coal-fired power plants," 2017.

[24] J. I. Huertas, M. D. Gomez, N. Giraldo, and J. Garzón, “CO2 Absorbing Capacity of MEA," J. Chem., vol. 2015, no. 2, 2015.

[25] José and R. De Andrade, "Design and Operation Optimisation of a MEA-Based CO 2 Capture Unit," no. November, 2014.

[26] P. Luis, "Use of monoethanolamine (MEA) for CO2 capture in a global scenario: Consequences and alternatives," Desalination, vol. 380, pp. 93-99, 2016.

[27] L. Zhu, Y. He, L. Li, and P. Wu, "Tech-economic assessment of second-generation CCS: Chemical looping combustion," Energy, vol. 144, pp. 915-927, 2018.

[28] O. Schmidt, A. Gambhir, I. Staffell, A: Hawkes, J. Nelson and S. Few, "Future cost and performance of water electrolysis: An expert elicitation study", Int. J. Hydrogen Energy, vol. 42, pp. 30470-30492, 2017.

[29] www.hydrogenics.com/wp-content/uploads/HyLYZER 600 3MW.pdf

[30] M. Asif, X. Gao, H. Lv, X. Xi, and P. Dong, "Catalytic hydrogenation of CO2 from $600 \mathrm{MW}$ supercritical coal power plant to produce methanol: A techno-economic analysis," Int. J. Hydrogen Energy, vol. 43, no. 5, pp. 2726-2741, 2018.

[31] A. A. Kiss, J. J. Pragt, H. J. Vos, G. Bargeman, and M. T. de Groot, "Novel efficient process for methanol synthesis by CO2 hydrogenation," Chem. Eng. J., vol. 284, pp. 260-269, 2016.

[32] G. Bozzano and F. Manenti, "Efficient methanol synthesis: Perspectives, technologies and optimization strategies," Prog. Energy Combust. Sci., vol. 56, pp. 71-105, 2016.

[33] E. Sanchez Fernandez et al., "Operational flexibility options in power plants with integrated post-combustion capture," Int. J. Greenh. Gas Control, vol. 48, pp. 275-289, 2016.

[34] International Energy Agency, "Power Generation from Coal," Coal Ind. Advis. Board, pp. 13-14, 2016.

[35] L. Irlam, "Global Costs of Carbon Capture and Storage - 2017 Update," no. June, p. 14, 2017.

[36] C. R. Gentry, "Reducing the cost of CCS," Chain Store Age, vol. 75, no. 10, pp. 124-126, 1999.

[37] H. J. Herzog, "The Economics of CO2 Separation and Capture," Technology, vol. 7, no. 1, pp. 2-19, 2000.

[38] J. David and H. Herzog, "The Cost of Carbon Capture," Energy, pp. 13-16, 2000.

[39] S. Lefton, "Power Plant Asset Management: Cost Analysis and Cost-Based Power Plant Asset Management - Thermal Power Plant Cycling Costs."

[40] https://www.eex.com/en/market-data/environmental-markets/spot-market/european-emission-allowances, last access 28/05/2018

[41] Ricerca sul sistema energetico-RSE SpA, "Energia elettrica, anatomia dei costi", editrice alkes, 2014.

[42] W.-P. Schill, M. Pahle, and C. Gambardella, "On Start-up Costs of Thermal Power Plants in Markets with Increasing Shares of Fluctuating Renewables," 2016.

[43] IEA Clean Coal Centre and H. Nalbandian-sugden, “Operating ratio and cost of coal power generation," 2016.

[44] U.S. Energy Information Administration (EIA), "Capital Cost Estimates for Utility Scale Electricity Generating Plants," 2016.

[45] National Energy Technology Laboratory (NETL), E. Grol, and T. J. Tarka, "Impact of Load Following on the Economics of Existing Coal-Fired Power Plant Operations," 2015. 
527 [46] K. Gerdes, W. M. Summers, and J. Wimer, "Cost Estimation Methodology for NETL Assessments of Power Plant 528 Performance," Doe/Netl-2011/1455, p. 26, 2011.

529 [47] National Renewable Energy Laboratory, "Cost and Performance data for Power Generation Technologies," 2012.

530 [48] M. Hermans, E. Delarue, and KU LEUVEN, "Impact of start-up mode on flexible power plant operation and system cost," 5312016.

532 [49] B. P. Breeze, "The Cost of Power Generation Paul Breeze," Bus. Insight, 2010.

[50] A. Schröder, F. Kunz, J. Meiss, R. Mendelevitch, and C. von Hirschhausen, "Current and Prospective Costs of Electricity Generation until 2050 2013," 2013.

[51] N. Kumar, P. Besuner, S. Lefton, D. Agan, and D. Hilleman, “Power Plant Cycling Costs," no. April, 2012.

[52] H. Nalbandian-sugden, "Operating ratio and cost of coal power generation," vol. 44, no. December, pp. 0-1, 2016

[53] M. R. M. Abu-Zahra, J. P. M. Niederer, P. H. M. Feron, and G. F. Versteeg, "CO2capture from power plants. Part II. A parametric study of the economical performance based on mono-ethanolamine," Int. J. Greenh. Gas Control, vol. 1, no. 2, pp. 135-142, 2007.

[54] I. Rossi, A. Sorce, and A. Traverso, "Gas turbine combined cycle start-up and stress evaluation: A simplified dynamic approach," Appl. Energy, vol. 190, pp. 880-890, Mar. 2017.

[55] Private comunication by Hydrogenics

[56] “Chemicals Pricing Data \&amp; Production Cost Reports - Intratec." [Online]. Available: https://www.intratec.us/. [Accessed: 5 December 2018]

[57] "Methanex Corporation." [Online]. Available: https://www.methanex.com/our-business/pricing. [Accessed: 31-January2019]

[58] https://www.globalpetrolprices.com/ [Accessed: 10 February 2019] 